\title{
Indigeneity behind the Scenes: Invasion and Kriolisation
}

\author{
Martin Préaud
}

Postdoctoral fellow, SOGIP program, LAIOS-EHESS, France.

etropic 14.2 (2015):11- 21. http://www.reefandleaf.com.au/etropic.html \& http://www.jcu.edu.au/etropic

\begin{abstract}
This paper seeks to explore the relations between Indigenous and Creole modes of existence and political situations. It combines a theoretical and ethnographic approach to explore the Aboriginal concept of "law and culture" as it emerged in the Kimberley region of Australia. In retracing the historical conjuncture that gave rise to the emergence of this concept into an Aboriginal regional organisation, it highlights important similarities between the developing politics of indigeneity in Australia and the processes of creolisation. Different translations of "law and culture", a concept expressed in Kriol, allow for a processual understanding of cultural and political change within Aboriginal societies and in their relation to the broader Australian society. Although Kriol is considered a linguistic phenomenon rather than a cultural or political one in the Australian context, it points to specific historical and social processes that are crucial to understanding the conditions in which Indigenous subjects are able to enunciate and articulate their position. By situating creolisation in the broader context of settler colonialism, I argue that it is a necessary counterpart of indigeneity, but one that needs be silenced and made invisible.
\end{abstract}

\section{Indigeneity behind the Scenes: Invasion and Kriolisation}

I know it's a white man system we're doing, dealing for funding and everything, but our old people bin done it before time when white man came. They done it with no money. And I feel proud of what they done, left behind for us.

Kurinjpi Ivan McPhee, 2004

(quoted in KALACC, 2007, p. 92)

\section{Introduction}

Kurinjpi was a Walmajarri man who had been brought up on Kimberley cattle stations in northern Western Australia. He was a public figure in the Aboriginal movement against the drilling of Kimberley ground at Noonkanbah and an important activist who played a key role in the establishment and operation of the three regional organisations created by Kimberley Aboriginal people: the Kimberley Land Council (KLC), the Kimberley Language Resource Centre (KLRC), and the Kimberley Aboriginal Law and Culture Centre (KALACC). He passed away in 2011 at the Ngalapita outstation he helped establish near Noonkanbah. The words of Kurinjpi Ivan McPhee introduce us to a paradox in which Indigenous realities are founded, that which links the continuity of Aboriginal practices and societies to the experience of colonisation. Young people, as opposed to the "old people", operate in the foreign system established by the white settlers but they do so on the basis of models established by the old people that use other means of exchange than money and seek other 
kinds of production. In this case, doing things differently is a means to keep doing the same. As invaded peoples, Aboriginal people have long learnt to exploit the interstices and limits of settler-colonial power in order to maintain the integrity of their institutions; in the more recent generations the problem has been to do so from within the ever-growing administrative framework organizing Aboriginal affairs.

This article seeks to manage some of the paradoxes that define indigeneity as a political position through an exploration of the relationship between two cultural and political processes, namely creolisation and indigeneity. To do so, it develops a historical and ethnographic understanding of both the concept of Law and Culture and the organisation that embodies it in the Kimberley region. In keeping with the theme of the colloquium that gives rise to this special edition - 'behind the scenes' - it suggests that creolisation is the necessary though invisible counterpart of indigeneity. Outlining the reasons for this invisibility is an important objective of this paper.

\section{Setting the Scene: Indigeneity, Kriolisation and Invasion}

In this paper, I use the term indigeneity to refer to a political situation articulated to a specific field of power and relationships. It is not an attribute of particular peoples or groups of people but, rather, an emergent property of colonial history, especially settler-colonial history, and generally expressed through an antagonism between indigenous collectives and the state. In its contemporary form, however, indigeneity is negotiated and discussed both at the international level where, as a result of indigenous peoples' mobilisation from the 1970s onwards, it is expressed in terms of rights, and at the national level where, as soon as settler collectives obtained a measure of self-government and autonomy, it has been defined as a particular status and managed through specific legislative and administrative frameworks, effectively separating indigenous peoples from the rest of the national population.

This state-managed version of indigeneity has been the main trigger for the engagement of indigenous peoples on the international stage which was conceived of as a means to circumvent the power of the states through reaching to a "higher authority" (da Costa, 2006) in order to express indigeneity in terms of human rights ${ }^{1}$. The United Nations Declaration on the Rights of Indigenous Peoples, negotiated over 20 years, embodies this movement. It establishes indigenous collectives as Indigenous peoples, thus as a new subject of international law holding the right to self-determination (Allen \& Xanthaki, 2011; Bellier \& Preaud, 2012). The international recognition of indigenous peoples through the Declaration signals a shift in conceptions of national sovereignty under processes of globalisation whereby territorial and political sovereignty no longer coincide. In this context, indigeneity can be seen as having emerged from the shortcomings of decolonizing processes in situations where the independent state is one built by settlers rather than colonized peoples. As such, indigeneity is intimately related to the particular phenomena of settler colonialism. On both counts - indigeneity as a political field articulated at various political scales, and settler colonialism as a specific political situation - Australia constitutes a paradigmatic example.

\footnotetext{
${ }^{1}$ In Australia, such a trigger has been the 1998 Amendments to the Native Title Act 1993 (Cth) and the recognition within ATSIC that an impasse had been reached (L. Malezer, pers. Comm.).
} 
Creolisation, on the other hand, is not generally associated with Australia. Etymologically, "creole" designates that which is born in the New Worlds created by European colonial expansion. It broadly refers to processes of linguistic, cultural and social innovation characteristic of colonial settings involving violent displacement and the grouping of heterogeneous peoples under colonial rule. Although primarily used in linguistics, the term has been used extensively by anthropologists in the last few decades, although in very different ways. While in the English-speaking world creolisation has been used in globalisation studies as a synonym for cultural mixing and hybridity (for instance in Drummond, 1980; Hannerz 1996), French anthropologists have used it to describe societies and languages developed in colonial plantations by African slaves and their descendants. Benoist, for instance, defines creolisation as "this series of changes due to the transfer of populations, the coalescence of different cultures, their molding under the heavy constraint of the hierarchical societies of colonial plantations, and to the emergence of a specific island society" (1996, p. 118, my translation) ${ }^{2}$. A sort of middle ground between these two uses of creolisation can be found in the work of Guadeloupian philosopher and writer Edouard Glissant for whom "creolisation is the bringing into contact of several cultures, or at least several elements of distinct cultures, in a place of the world, with the outcome of a new datum, totally unpredictable from the sum or the simple synthesis of these elements” (1997, p.37).

Although Kriol has become the main language spoken by Indigenous peoples throughout northern and central Australia, it has not been considered as anything other than a linguistic phenomenon (Munro, 2000). While its exact origin is still debated among linguists, the emergence of Kriol is intimately linked to the process of settlement and "pacification". It stems from the advance of the pastoral frontier and the establishment of colonial institutions cattle stations as well as prisons and Christian missions - where Aboriginal people, in the Kimberley as elsewhere, were displaced or regrouped, and put to work (Biskup, 1973; McGrath, 1987). The conditions of emergence of Australian Kriol thus closely resemble those that presided over the emergence of other creole languages in colonial plantations (Preaud, 2014). The diffusion of Kriol and its becoming a mother tongue for most Aboriginal people in northern and central Australia is more recent and is linked to the turn in indigenous policy that followed the 1967 referendum; the language was systematically described during the 1980s by linguists from the Summer Institute of Linguistics (Hudson, 1983; Harris, 1986; Sandefur, 1986), its regional variations according to substrate languages outlined as well as its links with dialectal forms of Aboriginal English. Its full recognition as a language by Australian institutions, for example in education, remains highly contested to this day (Ponsonnet, 2010). In this context it is not highly surprising that creolisation as a sociocultural process of innovation under duress - which can be referred to refer to as kriolisation to root it in the Australian landscape - has found very little venue for its expression.

Indigeneity and creolisation are seldom, if ever, discussed together. Mostly because those terms appear to be mutually exclusive: one cannot be indigenous and creole because creole evokes mixing and cultural transformation while indigeneity signals a longue durée of

\footnotetext{
2 « Cette série de changements dus au transfert des populations, à la coalescence de cultures différentes, à leur moulage sous la contrainte pesante de la société hiérarchique des plantations coloniales et à l'émergence d'une société propre aux îles ».
} 
cultural continuity - Aboriginal people are often presented as the heirs of the longest continuing culture on Earth. However, as we have seen, Australian Kriol emerged in conditions comparable to other Creoles and the element of violence and displacement characteristic of the transatlantic slave trade is also very much present in the settlement of the Australian territory albeit in a different mode. Further, it could be argued that the reason why indigeneity and creolisation appear antagonistic is an effect of the settler-colonial mind rather than an accurate description of sociocultural practice.

Following the work of Patrick Wolfe and, more recently, Lorenzo Veracini, settler colonialism can be characterized by a "cultural logic of elimination" that seeks to displace, replace, or even erase, indigenous existences in those territories where settlers have elected to build society anew. Wolfe's formula, according to which in settler colonial situations "invasion is a structure, not an event" (1999, p. 2), provides the most succinct and trenchant definition of settler colonialism. It can be refined through the analysis of the dialectics of inclusion and exclusion of indigenous people that characterize the settler state. Indigenous people, in this light, can only become part of the national settler community on the basis of their future disappearance (Veracini, 2011); thus is invasion made permanent, re-establishing a binarism that discourses on multiculturalism, hybridity and the dynamics of frontiers often tend to erase. In short, settler colonialism establishes a political situation where indigenous peoples and settlers can never quite meet - which should raise the issue of their modes of coexistence - and where forms of state recognition are also means to manage and neutralize indigenous difference, for instance by defining criteria of authenticity in order to obtain certain rights, especially in relation to land - what Wolfe (1999) discusses as forms of "repressive authenticity". In this particular juncture, it is impossible for Aboriginal people to present themselves as creolized because it would mean their disappearance as Indigenous peoples both in the international and national meanings attached to this term. But this does not mean that there are not creolizing processes at work; in fact, it could even be said that, to some extent, indigeneity is the form taken by creolisation in a settler-colonial setting. An exploration of Kimberley Aboriginal law and culture should serve to illuminate that point further.

\section{Law and Culture: A Kriolising Device in a Settler World}

The Kimberley Aboriginal Law and Culture Centre (KALACC) is one of three regional organisations of the Aboriginal Kimberley. In the landscape of Aboriginal Australia, the Kimberley region is somewhat exceptional for its level of organisation at a regional scale, all the more so given the heterogeneity of its Indigenous background. At the time of settlement, which started in 1881, the Kimberley was densely populated (Pedersen \& Woorunmurra, 1995) and there were an estimated 60 languages spoken in the Kimberley related to five different language families, which represents one of the highest level of linguistic diversity encountered in Australia (McGregor, 2004). As each language corresponded or belonged to specific tracts of country and groups of people, this linguistic diversity is indicative of an equally diverse cultural landscape. The expression of a single regional Kimberley Aboriginal identity can only be, then, the result of an active process of identity formation.

The expression of this regional Aboriginal identity first emerged in the late 1970s, during the Noonkanbah dispute, at a time when the liberation from colonial control (with the repeal of the Aborigines Act 1905 WA and the federal policy of self-determination) had translated into an Aboriginal political struggle for recognition of their land rights, particularly so in remote 
areas such as the Kimberley. During the dispute the Kimberley Land Council was established, a non-statutory body emulating the Land Councils established in the Northern Territory under the Aboriginal Land Rights Act 1976 (NT). In 1984, following the failure of the WA government to take action on Aboriginal land rights, two other regional organisations were established by the same people that had founded the KLC, during a cultural festival at Ngumpan/the Pinnacles - an illegal outstation established to protest working conditions on Christmas Creek station; the Kimberley Language Resource Centre and the Kimberley Aboriginal Law and Culture Centre.

The three organisations shared similar representative structures whereby all language groups were represented on a board by people nominated within their language group. In practice, these people were those who could speak for their country or language or law, which meant that they were selected among religious leaders. These leaders arguably found in those organisations the means to translate their ritual authority into a political one: "old people are our government” (KALACC, 1995). The "old people” who founded the Kimberley regional organisations had all lived their adult lives in colonial institutions such as missions and cattle stations, and a significant number had seen the arrival of the Kartiya on their country in their youth $^{3}$. In sum, it was a generation that had lived through the colonial moment and seen conquest turned into an enduring political situation.

Settlement in the Kimberley took off in the 1880s, following the first crossing of the Kimberley by a white man and, a little later, the discovery of gold near Halls Creek. Initiated by pearlers, it was mostly the act of pastoralists, bringing sheep from southern Western Australia and cattle from Queensland. Settlement followed a typical pattern outlined by Wolfe (1994): confrontation, incarceration and assimilation. First a time of armed installation, variously known as 'pacification' or 'killing times', which saw the decimation of Aboriginal population through diseases and massacres, massive deportation to prisons and hospitals, as well as missionary installation and episodes of armed resistance; it was during that period that Western Australia negotiated self-government from the British Crown and devised a "protection” regime towards Aboriginal people, namely an administrative framework of separation and control. A second period combined incarceration with economic exploitation and cultural assimilation; in the Kimberley, this meant working on cattle stations for rations of flour, sugar and tea, or being taken from your Aboriginal mother to be educated on a mission or a public institution elsewhere in the state. On cattle stations, children of mixed descent generally benefited from an exemption to the policy of removal in order to guarantee a sufficient workforce for cattle stations managers, some of them being infamously known for claiming to be "breeding their own labour". The Award Wages in 1969 led to massive departure from cattle stations and the installation of Aboriginal people around urban centres and missions, where they undertook the task of giving the federal self-determination policy some practical content. They started establishing communities, businesses and organisations and, following the Native Title Act 1993 (Cth), land claims - a process that continues to this day with $70 \%$ of the Kimberley landmass determined in favour of claimant groups under the NTA.

\footnotetext{
${ }^{3}$ Kartiya is the term used in the Kimberley to describe non-Aboriginal people, or people that are not socialised in a local kinship system.
} 
In many respects, colonial institutions of the Kimberley - missions and cattle stations mostly - resemble the plantation economy that characterizes Creole situations in the Caribbean or the Indian Ocean. Not only did Aboriginal people constitute a captive workforce under the unilateral authority of their various colonial "protectors", they were also regrouped in collectives that could not have existed prior to settlement. People who had not met before and had no established pattern of relationship were brought into direct contact with one another. New communities were thus formed on cattle stations and within missions, particularly in institutions hosting "stolen” children and on the southern Kimberley stations to which groups from the Great Sandy and Western Desert - Mangala, Walmajarri, and Wangkajungka people - came, willingly or not, to work.

The coming out of the desert from the 1920s onwards may be one of the most important events in Kimberley Aboriginal cultural history in the $20^{\text {th }}$ century. The installation of desert people on the southern fringes of river country - and on all stations around the desert, from Jigalong, to Waburton or Papunya, forming what Akerman (1979a) described in the late 1970 s as a "ring of fire" around the desert - led to important reconfigurations of the local Aboriginal sphere in terms of exchange, ritual, and kinship. Nomadic rituals in particular, or wanderkulte as they were described by their German ethnographers from the Frobenius expedition - Kurangara, Worgaia, and Juluru (see Widlock, 1992 for a comprehensive discussion of these cults in terms of praxis) - had a profound impact on both local ritual practice and forms of exchange; further, they have been foundational to new forms of political engagement by removing the link between territorial affiliation and ritual practice: In one sense, the worgaia transcends local languages and mythico-ritual boundaries. As it continues its embracing movement into the west, its own land-based context becomes divorced from its message [...] These factors are important because many of its adherents are, in fact, removed from their own particular territories. The worgaia, then, can be seen as a vital mechanism, unifying all Aborigines brought within its embracing power (Akerman 1979a, pp. 240-41).

When, in 2007, I asked the KALACC Walmajarri Chairman to offer a translation of "law and culture" into his language, he replied with two words: wunan and kuruwarri; interestingly enough, both these terms come from other languages than Walmajarri. Wunan refers to a network of territorialised ritual exchange which has its heart in Ngarinyin country, in the northern Kimberley. It is similar in its classic form to other exchange networks found throughout Aboriginal Australia (Thomson, 1949) whereby items of exchange move in specific directions between identified individual partners who are attached to specific places. However, when Akerman (1979b) drew a map of the Kimberley exchange network, quite a different picture emerged. His network did not so much link people as those communities that had been established on the ruins of colonial institutions by its former hosts, irrespective of tribal identity. The circulation of rituals in the 1960s and 1970s could be then seen as having served to establish these new routes and modalities of exchange that Kolig described as a "change in consciousness" (1981). While it is subject to debate whether kriolisation amounts to a change of consciousness or simply adds new layers and avenues for action, it is undeniably the case that the experience of massive loss of population followed by displacement to colonial institutions, as well as the establishment of desert groups on river country, have led to significant changes in Aboriginal sociocultural organisation. The point, however, is that the colonial constraints did not wholly determine Aboriginal peoples' reactions: on the contrary, it could be argued that it is the operation of classic Aboriginal institutions in brutally transformed circumstances that have led to these sorts of 
transformations. If, according to Morphy, "indigenous sociality can only be adequately modelled in terms of anchored networks" (2010, p.7), then Wunan provides a way to historicise the modes and practices of circulation and anchorage.

Kuruwarri, on the other hand, allows us to understand the cultural regime of historicity that underpins Aboriginal networks in history. A Western Desert word, it can be translated as image, trace, or even painting (Michaels 1992); but ethnographers like Poirier and Glowczewski insist on the active dimension of the term and translate it as "force-image" and "vital-essence” respectively (Glowczewski, 1991; Poirier, 1996): "more than a simple representation, such images are a direct manifestation of ancestral beings and their action" (Poirier, 1996, p. 56). KALACC chairman translated it as "heritage" which can lead us to translate Kuruwarri as "living heritage", in the literal sense of the term: one that has to be performed to remain effective and relevant - alive - in the situation of its performance. One is here reminded about Christie's comment on the gesture of galtha in the Yolngu context of north-eastern Arnhem Land, where it concludes the negotiations preceding a ritual over what ritual episodes should be performed by which clans attending the ritual: "In the Yolngu world, it is not so much that every reality has an inherent structure, but rather that every structure can be seen to inhere in a whole range of realities” (1992, p.7). Kuruwarri, in this context, can be understood as the material expression of such mythico-ritual structures, their projection in the actual world in order to provide means of action to the collective formed by its very expression - each Kuruwarri being owned or managed by various groups within a given local social system. Another illustration of this idea can be found in Sutton's description of the multiplicity of possible landed entities than can be "cut out" from Aboriginal networks, forming various countries according to the issue at stake (1995, p. 42). To sum up, Kuruwarri points to a form of social practice that dynamically produces various collectives according to the situation to be acted upon; there is not one Aboriginal society but a multiplicity of possible collectives that can be (per)formed to respond to specific circumstances.

Thus the creation of regional representative organisations during cultural festivals - when people from throughout the region are gathered in the one place - becomes understandable as situated within an Aboriginal history of dynamic and networked group-making. It is a cultural response to the injunction to form the representative structures necessary to the implementation of the various public policies regrouped under the umbrella of "selfdetermination”.

Taken together, Wunan and Kuruwarri provide us with a means to understand "law and culture" as a unitary concept that describes the ongoing passage from potential to actual: from what is under - hidden, subterranean, undisciplined and virtual; to what is on top - actual, anchored and effective. In this light, Aboriginal Law and Culture help us think of traditions, whether cultural or political, in terms of performativity and performance, in opposition to constructivist models of cultures and traditions (Barth, 1969). Rather than construction, Law and Culture points to enunciation or articulation, which accounts both for a long continuity of a ritual Law based on practice rather than content, and for a dynamic culture that can appropriate all the terms that are constitutive of the situation in which it is manifested. It thus offers a formula to illuminate the ongoing actualisation of a society and its institutions to the events of its history, and to develop a specifically Aboriginal history that cannot be reduced solely to the colonial experience but flows from the operation of Aboriginal institutions, albeit in troubled circumstances. Such a process can become kriolisation when it is brought to bear in a historical conjuncture of violence, displacement and unequal relationships with a 
radically different group, the Kartiya, with whom no relation is established. Kriolisation could then be seen as a means to propose a common front vis-à-vis the Kartiya in order to establish with them reciprocal relationships. In this sense, Law and Culture effectively indigenise creolisation into kriolisation, building on this process to produce a local version of Indigeneity to confront settler-colonial institutions.

Indeed, Law and Culture as a process, does not result in a complete mixing and merger of local cultural groups; on the contrary, and because it is rooted in a society where difference is the condition for productive exchange, local singularities are maintained and heightened and find their most common expression in the political formula according to which "no one can speak for someone else's country". In other words, kriolisation operates as another layer of relations and networks but does not erase or supersede those in which it is rooted.

\section{Behind the Scenes}

As an organisation, KALACC stems from the kriolising background that has made possible the (unpredictable) emergence of a regional Indigenous political subject. This background is made evident in the diffusion of the Kriol as a maternal language, replacing local languages and the lingua franca that Walmajarri was until the 1970s in the south and west Kimberley (Hudson, 1983); in the use of the subsection system as a common frame of reference for kinship throughout the region; in the emergence of new religious practice, nomadic rituals and cultural festivals; and in the territorialisation of the wunan system of exchange in the socalled "postcolonial” geography of Aboriginal communities, outstations and organisations. It is important here to emphasise that when Kimberley Aboriginal people were sent away from pastoral stations, they immediately thought to re-establish themselves on country but, importantly, in communities that were not linked to religious territorial affiliation, but rather, to common residence and work on cattle stations; the re-tribalisation of communities is more an effect of the Native Title Act operation with its insistence on proving the existence and continuation of "traditional" societies conforming to the outdated model thereof established by Radcliffe-Brown (Glaskin \& Dousset, 2011).

Being a product of kriolisation, KALACC puts forward in the Australian public space, in Kriol, the concept of Law and Culture. As with the term "business" commonly used by Aboriginal people to refer to ritual activity, Law and Culture informs us on the perception by Aboriginal people from the Kimberley of what they see as centrally important in settler society, and to engage with it on those terms. As such it can also be seen as a kriolising device, or at the very least as an attempt to disrupt settler-colonial categories that determine the Australian Indigenous sector of administration and to engage relationships with this administration on Kimberley Aboriginal peoples' terms. Law and Culture, indeed, do not fit easily into the administrative framework which generally distinguishes between "law and order" and "arts and culture". By linking the two domains, in its name and also in its activities, the organisation promotes a specifically Aboriginal viewpoint on addressing social issues. For instance, members of KALACC developed the Yiriman Project, a youth-at-risk program which seeks to reconnect young people with their country law and culture by bringing young people back on country with their elders. Here, again, is a cultural response to high levels of suicide among young people, one that breaches conventional partitions of the administration but that was nonetheless awarded an Indigenous Governance Award in 2012, ten years after its foundation. 
As a kriol device, KALACC has constantly confronted the various forms of "repressive authenticity”, “deep colonialism” and "cunning of recognition” that characterise the management of Aboriginal affairs by Australian governments (Wolfe, 1994; Rose, 1996; Povinelli, 2002). In fact it could be argued that these settler colonial devices are precisely going against kriolisation processes by producing an accepted version of Indigeneity that is not politically threatening. It is characteristic in this regard that the organisation has been funded for its 21 first years of existence (1984-2000) purely as a cultural organisation. One of the principal activities of KALACC, and a primary reason for its establishment, remains the organisation of the "Law season" by providing support - mostly food and fuel - for communities to organise initiation rituals in the bush. By framing it as a "cultural" activity to obtain pubic funding, the activity itself cannot be recognised for its major social, political and economic role in the communities concerned; it is neutralised as a central institution of Aboriginal societies and reconstructed as an aesthetic concern. As the KALACC chairman put it in 2006: "Well I think that, it's between Aborigine and government just like war now, you know, it's the war with talking and the fighting talking, that's what [all around] us you know" (personal interview, $8^{\text {th }}$ August 2006). That Law, in the end, came to be funded for what it is without having to be disguised, is a testimony to the fact that some little victories can be won in this war of words and recognition.

However, the fact that creolisation remains absent in academic and political debates on Aboriginal Australia also goes to show the firmness of the settler-colonial framework. As we have seen, a settler-colonial situation imposes a binary relationship between settlers and Indigenous peoples. This situation prevents any formation of a Kriol consciousness because it would amount to self-destruction for Indigenous peoples. Indigeneity as a political project imposes a silencing of historical transformations and of processes of creolisation in as much as authenticity is defined by the settler-state and its institutions. For while Aboriginal people defend their singularity in order to activate reciprocal relations between partners, using difference as the basis for exchange, the state constructs this difference within an unchanging framework of unequal relationship, thereby maintaining the colonial nature of the social structure, maintaining Indigenous peoples in a subaltern position which ultimately justifies their management by the state. The jurisprudence of the Native Title Act 1993 after its amendments, for instance in the Ward and Yorta Yorta decisions, are clear examples of this dynamic.

\section{Conclusion}

In this paper, I have attempted to argue that Aboriginal Australia has a Kriol history, taking as a starting point the emergence of the Kriol language on the pastoral frontier and its subsequent transformation into an Aboriginal language. But creolisation is quite politically incorrect in a settler-colonial situation, disrupting both the indigenous position and the settler narrative. By analysing the history and concept of law and culture in the Kimberley, I have shown that there clearly are kriolising processes at work in Aboriginal political history and that they offer an avenue to explore a specifically Aboriginal political history that cannot be reduced to resistance to the colonial experience, but point to a longue durée of Aboriginal societies beyond the "colonial moment". In my attempt to translate Law and Culture from the Kriol to the English language, via a detour in Ngarinyin and Desert countries, I have pointed to the possible articulation between the concept of creolisation and historical cultural practice in the Aboriginal Kimberley using the term "kriolisation" to describe the Indigenisation of creolised practice. However, in turning the gaze towards social practice and the organisation 
that embodies the concept of law and culture, I have suggested that these kriolising processes that underpin the vitality of Aboriginal societies constantly run the risk of being interrupted by the very politics of recognition that the late settler-colonial state characteristically promotes through an aspiration for clarity and authenticity. While it certainly is an awkward task to articulate kriolisation and Indigeneity, such an attempt stems from an objective to take seriously the daily social practice of Aboriginal people over issues of legal and political status. Ultimately, because this articulation opens a space to rethink beyond binaries towards more heterogeneous and performative conceptions of social organisation and politics - and their unpredictable results - it may also provide an avenue for thinking about decolonisation in a political context predicated on its impossibility.

\section{Works Cited}

Akerman K. (1979a). The renascence of Aboriginal Law in the Kimberleys. In R. M. Berndt \& C. H. Berndt (eds.) Aborigines of the West: Their Past and Their Present. (pp. 234242). Perth: University of Western Australia.

Akerman K. (1979b). Material culture and trade in the Kimberleys today. In R. M. BERNDT \& C. H. BERndT, (eds.), Aborigines of the West: Their Past and Their Present, Perth: University of Western Australia, p. 243-251.

Allen, S. \& Xanthaki, A. (Eds.). (2011). Reflections on the UN Declaration on the rights of indigenous peoples.

Barth, F. (ed). (1969). Ethnic Groups and Boundaries: The Social Organization of Culture Difference. London: Allen \& Unwin

Bellier, I. \& Preaud, M. (2012). Emerging issues in indigenous rights: transformative effects of the recognition of indigenous peoples. The International Journal of Human Rights 16(3), 474-488. doi:10.1080/13642987.2011.574616

Benoist, J. (1996). Métissage, syncrétisme, créolisation : métaphores et dérives. Études créoles 19 (1), 47-60.

Biskup, P. (1973). Not Slave Not Citizens: The Aboriginal Problem in Western Australia 1898-1954. St Lucia: University of Queensland Press.

Christie, M. (1992). Grounded and Ex-centric Knowledges: Exploring Aboriginal Alternatives to Western Thinking. Unpublished paper presented at the $5^{\text {th }}$ Conference on Thought, Townsville (Qld), 22.

Da Costa, R. (2006). A Higher Authority: Indigenous Transnationalism and Australia. Sydney: UNSW Press.

Glaskin, K. \& Dousset, L. (2011). Asymmetry of Recognition: Law, Society and Customary Land Tenure in Australia. Pacific Studies 34(2/3), 142-156

Drummond, L. (1980). The cultural continuum: A theory of intersystem. Man 15(2), 352374.

Glissant, E. (1997). Traité du Tout-Monde. (Poétique IV). Paris: Gallimard.

Glowczewski, B. (1991). 1991a, Du Rêve à la Loi chez les Aborigènes. Mythes, rites et organisation sociale en Australie. Paris: PUF.

Hannerz, U. (1996). Transnational Connections. London: Routledge.

Harris, J.W. (1986). Northern Territory Pidgins and the Origin of Kriol. Canberra:

Department of Linguistics, Research School of Pacific Studies, Australian National University.

Hudson, J. (1983). Grammatical and Semantic Aspects of Fitzroy Valley Kriol (Work Papers of SILAAB) (Series A vol. 8). Darwin: SIL-AAB. 
KALACC (2007). New Legend: A story of Law and Culture and the Fight for SelfDetermination in the Kimberley. Fitzroy Crossing: KALACC.

KALACC (1995). Wire Yard Meeting Report, unpublished report.

Kolig, E. 1981. The Silent Revolution: The Effects of Modernization on Australian Aboriginal Religion. Philadelphia: Institute for the Study of Human Issues.

McGrath, A. (1987). 'Born in the Cattle': Aborigines in Cattle Country. Sydney, London \& Boston: Allen \& Unwin.

McGregor, W. (2004). The Languages of the Kimberley, Western Australia. London: Routledge Curzon.

Michaels, E. (1992). Yuendumu Doors/Kuruwarri. Canberra: Aboriginal Studies Press.

Morphy, F. (2010). Population, People and Place: The Fitzroy Valley Population Project. (CAEPR Working Paper 70). Canberra: ANU.

Munro J. M. (2000). Kriol on the Move: A Case of Language Spread and Shift in Northern Australia. In J. Siegel (ed) Processes of Language Contact: Case Studies from Australia and the South Pacific (pp. 245-70). Saint-Laurent, Que.: Fides.

Pedersen, H. \& Woorunmurra, B. (1995). Jandamarra and the Bunuba Resistance. Broome: Magabala Books.

Poirier, S. (1996). Les Jardins du Nomade. Cosmologie, territoire et personne dans le désert occidental australien. Munster: Lit Verlag [2005. A world of relationships: itineraries, dreams, and events in the Australian Western Desert. Toronto: University of Toronto Press].

Ponsonnet, M. (2010). “Brainwash from English”? Barunga Kriol Speakers’ Views on Their Own Language. Anthropological Linguistics 52 (2), 160-183.

Povinelli, E. A. (2002). The Cunning of Recognition: Indigenous alterities and the making of Australian multiculturalism. Durham: Duke University Press.

Préaud, M. (2014). Festival de Passages : Les Aborigènes du Kimberley se réunissent en Kriol. In L. Pourchez \& I. Hidair (Eds.), Regards pluridisciplinaires sur les rites de passage et les constructions identitaires créoles. (pp. 321-332). Paris: Edition des Archives contemporaines.

Rose, D.B. (1996). Land Rights and Deep Colonising: the Erasure of Women. Aboriginal Law Bulletin; 85 (3), 6-12.

Sandefur, J.R. (1986). Kriol of North Australia: A Language Coming of Age. Darwin: Summer Institute of Linguistics, Australian Aborigines Branch.

Sutton, P. (1995). Country: Aboriginal boundaries and land ownership in Australia. Canberra: Aboriginal History Inc. (Aboriginal History Monograph 3).

Thomson, D.F. (1949). Economic Structure and the Ceremonial Exchange Cycle in Arnhem Land. Melbourne: MacMillan \& Co Ltd.

Veracini, L. (2011). Introducing settler-colonial studies. Settler Colonial studies 1 (1), 1-12.

Widlock, T. (1992). Practice, politics and ideology of the 'travelling business' in Aboriginal religion. Oceania 63 (2), 114-136.

Wolfe, P. (1999). Settler colonialism and the transformation of anthropology: the politics and poetics of an ethnographic event. London \& New York: Cassell.

Wolfe, P. (1994). Nation and MiscegeNation: discursive continuity in the post-Mabo era. Social Analysis 36, 93-152. 